\title{
POST-COLONIAL LITERATURE IN ESL CURRICULUM: USING KAISAR HAQ'S “ODE TO THE LUNGI" IN AN ESL CLASSROOM
}

\section{Sultana Jahan}

Assistant Professor at Department of English Language and Literature

International Islamic University Chittagong

E-mail: sultanajahaniiuc@yahoo.com

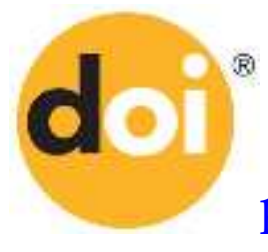

http:/ / dx.doi.org/10.26739/2573-5616-2017-8-8-7

Abstract: As literary texts include cultural uses of linguistic expression and reflection of social communication through the usage of different language aspects, many instructors are likely to be benefited using literary texts along with language structure in the ESL classroom. As literature often sheds light on the particular culture and authentic experience, the materials presented may not be familiar to ESL students who may find such text structurally complex. To overcome this problem the practitioner may introduce postcolonial/multicultural texts to meet the needs of cultural diversity. More importantly, the learners in this way get rid of the imposed Eurocentric vision and biases that deem the challenges and representations of various cultural groups. Postcolonial text may add different dimensions in teaching language stimulating imagination and offering real language use with cultural diversity. This approach will not confine the language teaching to the idea of connecting learners to their everyday world rather it stretches its landscape making the Social science and humanities

Generalization of scientific results 
students grasp their history and aware of the fact that language can be means of resistance and opposition. This paper aims to examine the ways of using Kaisar Haq's "Ode on the Lungi" as a postcolonial text in an ESL situation. As "Lungi" is a common garment in this subcontinent, this poem will act as a highly motivating material in the classroom where the learners will, as a byproduct, get awareness about the socially, politically and economically excluded people who are 'ridiculously' clad in modest lungis. Applying both efferent and aesthetic way of reading the learners will be able to experience a crispy postcolonial flavor in the language classroom.

Keywords: Literary, literature, multicultural, "Ode on the Lungi", "Lungi”.

\section{Introduction}

Using multi-cultural text in the EFL classroom creates alternatives for the students to relieve themselves from the imposition of the cultural complexities of native English. The complicated relationship between language and culture make the students fall into the fallacy that may make them confused - whether the literary works represent the totality of society or atypical depiction giving rise to imperialistic and distorted view. Using south-Asian literature in the EFL classroom in Bangladeshi context can shed light on several factors that will add different dimension in language learning. When the learners being free from cultural and ideological barrier, get the multiple levels of meaning of the literary text, they can easily express their own personal responses that hasten the acquisition of language. With decrying the traditional grammar-translation method and promoting communicative methods of language teaching, the acceptance of using literary text in ESL classroom is gradually stepped up. As CLT prescribes group activities, and language-learner's interaction (i.e. prediction, creating a scenario, debating, ) any piece of literature as authentic text creates a feeling for language. To contextualize linguistic appropriateness literary text written by non-native writer may be used. Literature should not be far removed for the learner's world that will be enriched with linguistic knowledge through contextually appropriateness. The success of CLT depends on how much the students are engaged with dialectic of meaning production and how much excess he has to the world of attitude and values. Most importantly, to engage the students with aesthetic reading that prompts the reader to relate their experience with the literary text, post-colonial text may be

Social science and humanities

Generalization of scientific results 
American Journal of Research

№ 8-9 (8-9), August-September 2017 www.journalofresearch.us

info@journalofresearch.us

fruitful. Language and culture are intricately connected and literature is the cultural product. In this connection, post-colonial texts help the learner to concentrate on and to focus his attention to the literary text that will quicken language acquisition.

\section{Infusing Postcolonial components into English Language Teaching:}

Though to some extent cultural barrier of the literary text by native writers creates unintelligibility to the learners, these texts are recommended in the ESL classroom for the high proficiency of the native author and their language expertise. However, such observation is not always reasonable. A large number of nonnative speakers in periphery countries are also shaping English language. Due to the ascendancy of English to global language, most speakers of English are non-native or second language speaker. Today the majority of the world's speakers of English are no longer monolingual speaker living in the center. These nonnative varieties of English are not dealt with as socio-linguistic varieties though attempts may be made to include literary text by authors who choose to write in English as second or other language. This is not the question of introducing standards or nonstandard English in the ESL classroom rather to enhance students' awareness of the international varieties of English. English is a worldwide language and as such is used in an amazingly wide range of circumstance resulting in diversity. Furthermore, as Vethamani (2003) is of the view, English speakers "should be able to make the shift from standard to nonstandard forms or they may appear affected of phony in certain circumstances" (p. 5). To this, Crystal (1997, p. 138) further contends that in fact, people who can use both varieties are in a considerably powerful position over others who can use just one. They have a vernacular to express their national identity; What's more, they need an alternate vernacular which can guarantee international intelligibility, when they require it. In this case, therefore, EFL learners need to know when and to whom Standard English and varieties of the language should be used. Literary texts contain richer and more varied language that produces multi-layers of meaning. Therefore, students are presented with natural standard and non-standard forms of the variety of English. They can appreciate and experience of the richness of the linguistic varieties when reading the text. At the same time, they develop their awareness to appreciate all English varieties. Multi-cultural writings in the ESL classroom in this way

Social science and humanities

Generalization of scientific results 
American Journal of Research

№ 8-9 (8-9), August-September 2017 www.journalofresearch.us

info@journalofresearch.us

open up a new horizon for those learners in experiencing and enjoying the new wealth of language.

\section{Protection against Cultural Imperialism:}

Though the EFL learners are acquainted with the culture through literature beyond learning language, cultural aggression will be occurred through the communal relationship between literature and culture to the extent that learners' own cultures are relegated and sometimes even ignored. As Lazar (1993) warns us, "being made to read texts so alien to their own experience and background may only increase students' sense of frustration, inferiority, and even powerlessness (p. 3). One way to prevent from culture imperialism within literature-based EFL/ESL classrooms is to introduce "quality multicultural literature reflecting many cultures" (Vardell, et al., 2006, p. 736). With a view to making effective integration of literature into language classroom and adding multidimensional touch, teachers may make parallel among different cultural diversity so that the learners can perceive that besides enhancing the efficacy of their literary texts for the development of learners' communicative skills in the L2, they can use language as means of resistance and opposition exposing themselves to local cultural content, identities and value systems while learning the language. Accordingly, Mitchell and Myles (qtd in Tomlinson, 2000, p. 19) argue that experiencing literature can both facilitate language acquisition and help students to develop local and regional cultural awareness. The more they understand and empathize with other cultures, the more positive and constructive they can be (Tomlinson, 2000, p.20).

Motivation, the most important factor in language learning can be achieved when the literary text has relevance to the students' milieu. The familiarity of setting and culture removes many, but not all, of the obstacles (Sevier, 1994, p. 2). EFL/ESL learners are motivated to study as their ideas and experiences merge with what they are asked to read.

\section{Using Literature in the Classroom - Aesthetic Reading and Post coloniality:}

It is difficult for the teacher to engage the learners in aesthetic reading as they are used to efferent or non-aesthetic reading: they acquire information and find solution to the problem while reading the text. However, in aesthetic reading the reader does not shut out his inner reverberation but listening to himself. In

Social science and humanities

Generalization of scientific results 
American Journal of Research

№ 8-9 (8-9), August-September 2017 www.journalofresearch.us info@journalofresearch.us

language class, student can improve their writing skill through aesthetic reading in various ways-: learner can easily relate their experience with the text as they find the text is representing the particular voice of a writer belonging to his own culture or community. More importantly, this type of text provides familiar and fresh content thus evoking spontaneous response and engage them in the dialectic of meaning production and give access to the world of values. Alaistar Pennycook in "cultural politics of English as an international language" argues "English language teaching must start with ways of critically exploring student's cultures, knowledge and histories in ways that are both challenging and at the same time affirmative and supportive." (qtd in Fakrul Alam, 2007, p.380) In Resisting Linguistics Imperialism in English Teaching, Canagrajah emphasizes the importance of a pedagogy that will enable learners "to use English not mechanically and differently, but creatively and critically" (qtd in Fakrul Alam, 2007, p. 380). Literary text of their own community instills into them confidence needed to whack their own linguistics features. Such materials encourage them to express their own perspective on subjects and cultivate their self-importance in their own writers.

To implement such assumptions in the ESL classroom, teacher has to organize and accomplish every step very adeptly. Selecting the text is the first step. An equally important issue is how to deal with such texts in the classroom. Another worth-mentioning fact is that question may arise why I have selected poetry deviating from the norms of language. As a student of tertiary level, they should bear in mind that language is not absolutely and rigidly governed by rule as we think. As a language teacher it is my concern to make the students understand that breaking the rules of language poetry paves the way of experiencing original and fresh use of language that on the one hand makes a sharp contrast with the knowledge of norm or correct usage of language and on the other sensitize them to different and creative use of language. We take for granted that as the students of tertiary level they already have the knowledge about idealized language rule. Now they exploiting the unusual or deviant form of language, expand language awareness and interpretative ability.

To understand the literary text the learner must undergo the process of scaffolding that refers to the situation where learners "are challenged by a task beyond their current level of competence, but provided with task-specific support by a more competent adult or peer" (Murray \& McPherson, 2006, p.

Social science and humanities

Generalization of scientific results 
139). One good example of how teachers can employ the concept of scaffolding implementing a teaching scheme comprising several tasks. Teacher can categorized the tasks based on the following design:

A. Brainstorming and Contextualization of the task (through pictures, regalia, questions, and answers)

B. Illustration of the context Introduction of some of the key vocabulary items (through matching, predicting, and guessing).

C. Performing a similar task chorally

To illustrate my points, I have designed series of open-ended tasks for tertiary level students based on an excerpt of "Ode on the Lungi" a poem written by a Bangladeshi poet, Kaisar Haq. The very title of the poem indicates that apart from learning language, Bangladeshi students will be provided with innovative taste and sensitivity, as they will be conversant with their own culture, custom, heritage, resistance, and opposition as well.

Task1(warm-up/Review)

The teacher facilitates an activity with the following picture that enables the learners to prepare their mind. Teacher elicites from students information about the picture and instigates different questions in learners mind about lungi:

Why is it not used as formal dress in our country?

Is it used as formal dress in other countriess? 
American Journal of Research

№ 8-9 (8-9), August-September 2017 www.journalofresearch.us

info@journalofresearch.us

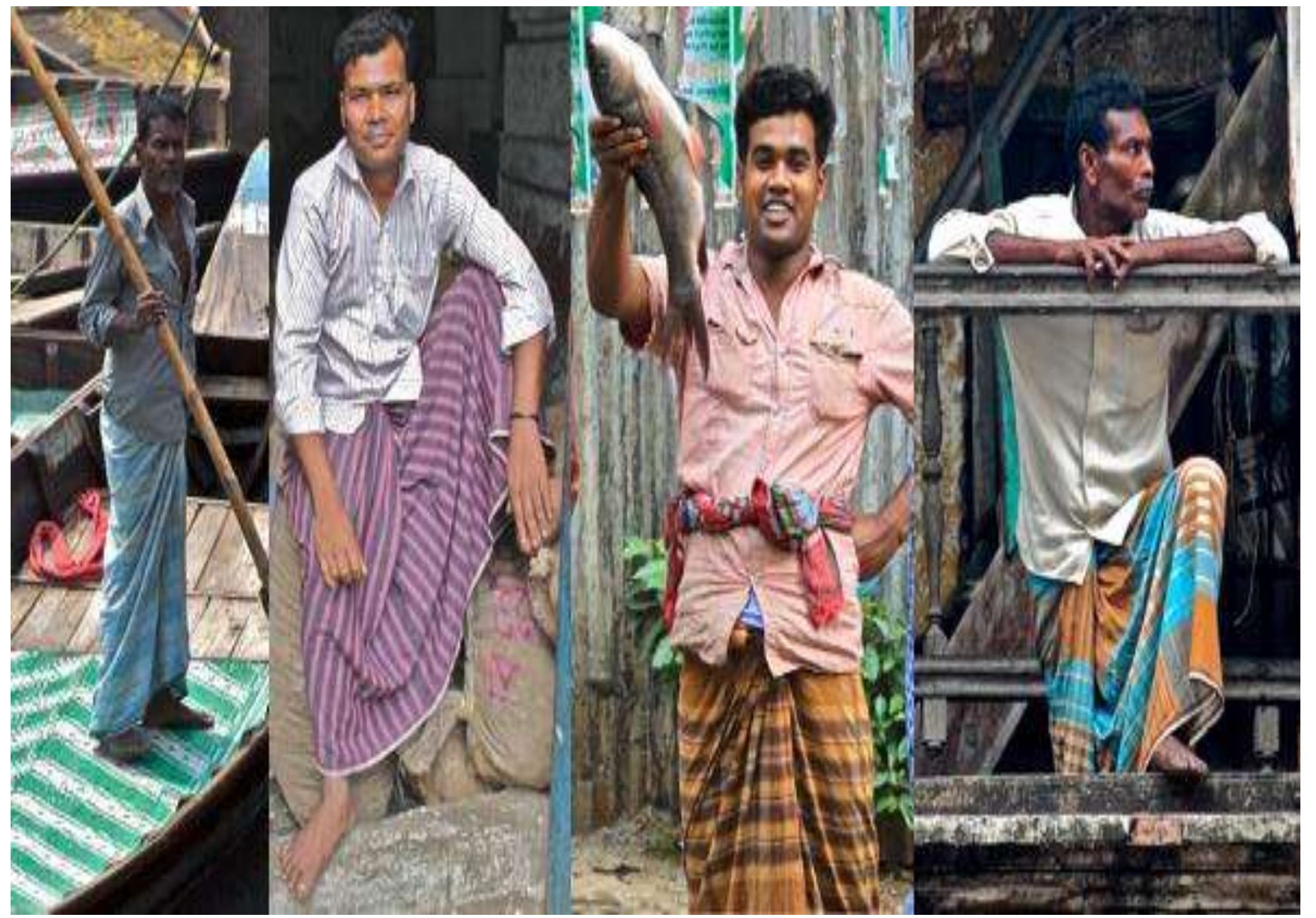

Social science and humanities

Generalization of scientific results 


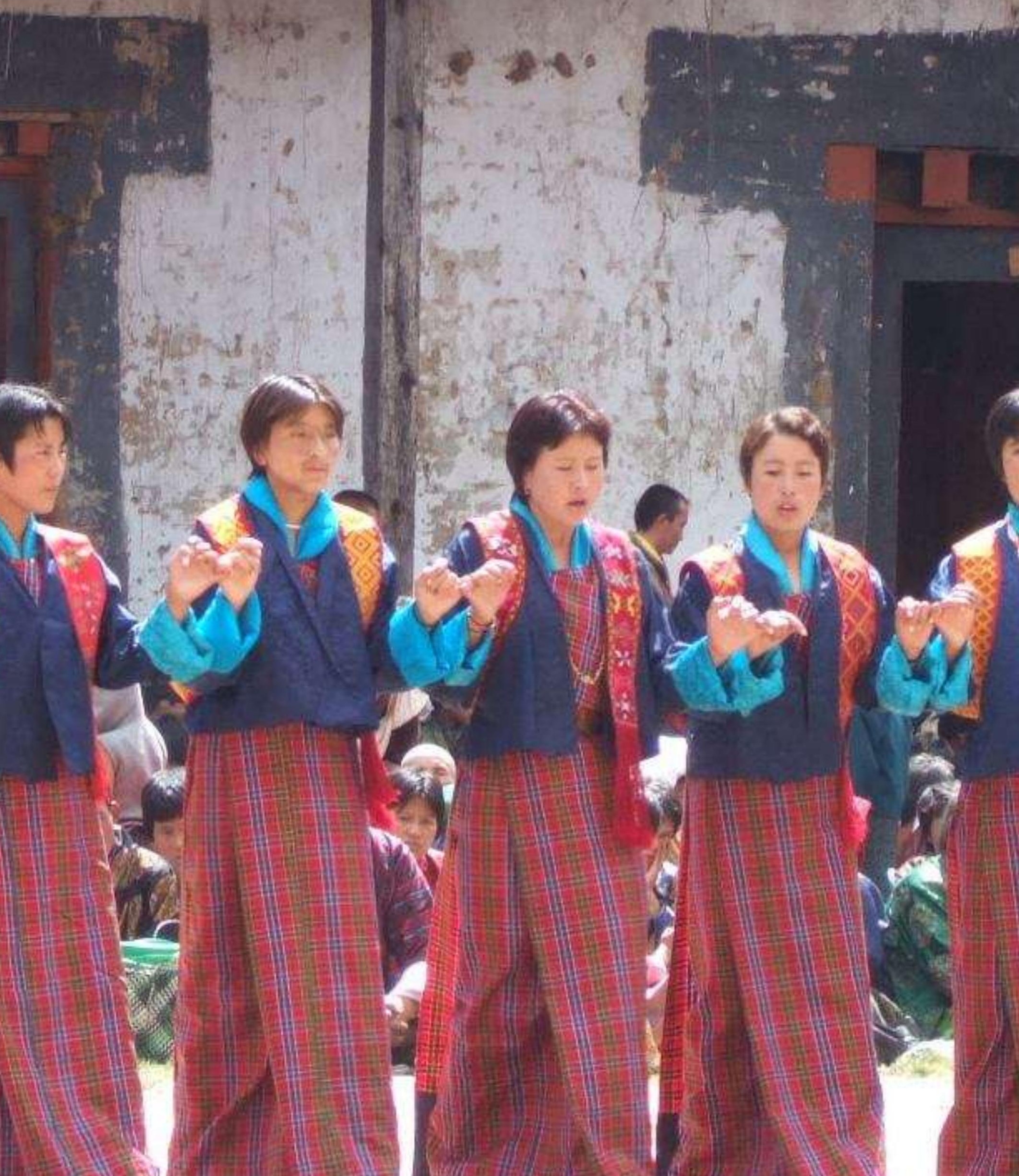


American Journal of Research

№ 8-9 (8-9), August-September 2017 www.journalofresearch.us

info@journalofresearch.us

Task 2

The teacher will read aloud the following information to aid the learners in having necessary information about the poet.

You are going to read a poem called 'Ode on the Lungi' by Kaiser Hamidul Haque who lived from 1950. Kaisar Haque has been described in the following ways:

-He is one of the few Bangladeshis who excel in creative writings in English. He is a professor of English at the University of Dhaka.

-Inthe liberation war of our beloved country, he fought against Pakistani Army "as a freshly commissioned subaltern in command of a company

-Haq's poems, mostly written in free verse in standard English and rooted in Bangladeshi life and culture availed him international acknowledgement as "a writer worth noticing".

-Although the poet writes in the colonial language, his writings are capable of creating the image of the native culture in their own ways and a glimpse of them will be reflected in the paper

-Haq's poetry is rich in emotional content and intellectual implications while being at once, ironic, quirky, zany. He has an eye for the telling image and an ear for the musical phrase.

Then the teacher may question like this:

In the light of what you know about Kaisar Haque's innovation, what do you think the poem 'Ode on the Lungi' is going to be about?

Task 3

Providing the necessary historical background through an extract from an interview of the writer himself

Social science and humanities

Generalization of scientific results 
American Journal of Research

№ 8-9 (8-9), August-September 2017 www.journalofresearch.us

info@journalofresearch.us

Students read or listen to the following extract:

....... English was a tool of colonisation, but it was a double-edged tool, $\mathcal{E}$ so when the anti-colonial movement got going the English language $\mathcal{E}$ the ideas that were conveyed through it played a role. Then, when the colonisers left, the subcontinent did not let go of the English language. There are wheels within wheels too. Recently the dalits in India celebrated Macaulay's birthday with great fanfare because they felt that learning English $\&$ being educated through English had enabled them to liberate themselves from the tyranny of upper caste Hindus.

By now, of course in the subcontinent as a whole there is a thriving tradition of writing in English. However, it is not free of controversy. That is a good thing. It is salutary that writers should question themselves $\mathcal{E}$ be questioned by readers $\mathcal{E}$ others. a sub continental who writes in English should keep on questioning his/her relationship with the language used.

However, there is also a kind of criticism that is too ridiculous for words. When someone says that a Bangladeshi should not write poetry in English, the statement is nonsensical. Let us analyse it to see why. One can ask if it is only poetry that should be put under a ban, or fiction and non-fictional prose as well. If it is only poetry that is under the interdiction $\mathcal{E}$ not the other two one can question why fiction should not be under the interdiction as well. If both poetry $\mathcal{E}$ fiction are under the interdiction, because both are forms of creative writing $\mathcal{E}$ the critic in question believes authentic creative writing can only be done in one's mother tongue, the question arises whether, when a Bangladeshi writes non-fictional English prose he/she should deliberately write badly or, if he/she writes well enough for his/her work to be considered of literary merit, he/she should be condemned. if he/she isn't condemned $\mathcal{E}$ is praised instead, how is it that his/her work is authentic when a fiction writer's or a poet's is declared a priori to be inauthentic? Creative non-fiction is often little different from fiction; what if the successful non-fiction writer now writes a novel: will it be condemned outright? $\mathcal{E}$ if fiction is considered to be ok, why not poetry, if the poetry deals with our situation successfully?

One could change tactics and argue that writing in English is bound to be a coterie affair in a country like Bangladesh $\mathcal{E}$ should therefore be discouraged. However, why? Why, if there is a coterie that enjoys writing in English $\mathcal{E}$ reading the stuff, should they not be allowed to enjoy themselves? Would we discourage a small ethnic Social science and humanities

Generalization of scientific results 
community from writing in their language? Besides, even if we take writing in Bengali, it is not read by everyone in the country. Most poetry collections in Bengali sell a few hundred copies; should the poets stop writing on that account?

Teacher will start up question-answer session from the afore-mentioned intervew:

-ask the students to read the excerpt

-ask the students to work in groups of 5(it is assumed that there will be 4 groups in the classroom)

-ask group A and B to have a discussion on the folloowing topic: writing poetry in English in the context of Bangladesh

-ask group C and D to discuss on the following topic: English is a double-edged tool.

-ask the representatives of the each group to present the result of their discussion.

\section{Task 4}

Teacher will distribute the following extract:

$$
\begin{gathered}
\text { Grandpa Walt, allow me to share my thoughts } \\
\text { with you, if only because every time } \\
\text { I read "Passage to India" and come across } \\
\text { the phrase "passage to more than India" } \\
\text { I fancy, anachronistically, that you wanted } \\
\text { to overshoot the target } \\
\text { by a shadow line } \\
\text { and land in Bangladesh }
\end{gathered}
$$

Lately, I've been thinking a lot

about sartorial equality

How far we are from

this democratic ideal!

And how hypocritical! 
"All clothes have equal rights" this nobody will deny and yet, some obviously are more equal than others

No, I'm not complaining about the jacket and tie required in certain places that, like fancy dress parties, is in the spirit of a game

I'm talking of something more fundamental

Hundreds of millions

from East Africa to Indonesia

wear the lungi, also known variously

as the sarong, munda, htamain, saaram,

ma'awaiis, kitenge. kanga. kaiki

They wear it day in day out, indoors and out

Just think -

at any one moment

there are more people in lungis

than the population of the USA

Now try wearing one

to a White House appointment -

not even you. Grandpa Walt,

laureate of democracy,

will make it in

You would if you affected a kilt -

but a lungi? No way.

But why? - this is the question

I ask all to ponder

Is it a clash of civilisations?

The sheer illogicality of it -

Social science and humanities

Generalization of scientific results 
the kilt is with "us"

but the lungi is with "them!"

Think too of neo-imperialism and sartorial hegemony, how brown and yellow sahibs in natty suits crinkle their noses at compatriots (even relations) in modest lungis, exceptions only proving the rule:

Sri Lanka, where designer lungis

are party wear, or Myanmar where political honchos queue up in lungis

to receive visiting dignitaries

But then, Myanmar dozes behind a cane curtain, a half pariah among nations Wait till it's globalised: Savile Row will acquire a fresh crop of patrons

Hegemony invades private space as well: my cousin in America would get home from work and lounge in a lungi till his son grew ashamed of dad and started hiding the "ridiculous ethnic attire"

It's all too depressing But I won't leave it at that The situation is desperate Something needs to be done I've decided not to 
take it lying down

The next time someone insinuates

that I live in an Ivory Tower

I'll proudly proclaim

I AM A LUNGI ACTIVIST!

Friends and fellow lungi lovers, let us organise lungi parties and lungi parades,

let us lobby Hallmark and Archies

to introduce an international Lungi Day

when the UN Chief will wear a lungi

and address the world

Grandpa Walt, I celebrate my lungi

and sing my lungi

and what I wear

you shall wear

It's time you finally made your passage

to more than India - to Bangladesh -

and lounging in a lungi

in a cottage on Cox's Bazar beach

(the longest in the world, we proudly claim)

watched 28 young men in lungis bathing in the sea

But what is this thing

(my learned friends,

I'm alluding to Beau Brummell)

I repeat, what is this thing

I'm going on about?

A rectangular cloth,

White, coloured, check or plaid,

roughly 45X80 inches,

halved lengthwise

and stitched

to make a tube

you can get into

Social science and humanities

Generalization of scientific results 
and fasten in a slipknot

around the waist -

One size fits all

and should you pick up dirt

say on your seat

you can simply turn it inside out

When you are out of it the lungi can be folded up

like a scarf

Worn out it has its uses as dish rag or floor wipe or material for a kantha quilt

Or you can let your imagination play with the textile tube to illustrate the superstrings of the "Theory of Everything"

(vide, the book of this title by the venerable Stephen Hawking)

Coming back to basics, the lungi is an elaborate fig-leaf, the foundation of propriety in ordinary mortals

Most of the year, when barebodied is cool, you can lead a decent life with only a couple of lungis, dipping in pond or river or swimming in a lungi abbreviated into a G-string, then changing into the other one Under the hot sun a lungi can become 


\author{
Arab-style headgear \\ or Sikh-style turban \\ Come chilly weather \\ the spare lungi can be \\ an improvised poncho \\ The lungi as G-string \\ can be worn to wrestle \\ or play kabaddi \\ but on football or cricket field \\ or wading through the monsoon \\ it's folded vertically \\ and kilted at the knee
}

To check the comprehension ability of the learners, teacher facilitates some groups and initiates the group discussion raising some questions into learners' minds:

Teacher will ask the students to comment on the text orally, what they think when they read it, if they have any experiences or information that they can share or why the poet takes the allusion of "Walt Whitman." They might also be asked to suggest the tone of voice used by the poet in making these references. Such activities would naturally result in an exploration of the role of cross-cultural assumption and ultimately lead to an examination of a central concern of the poetry. The ESL Classroom aesthetically cannot overlook this question: what is "sartorial hegemoni", neo-imperialism, connotation of "us" and "us" and so on. This discussion may lead back to a closer reading of the text. After reading the text, students might be asked if he is feeling proud reading such a familiar topic or does, they come across any interesting or new about the familiar topic.

\title{
Task 5
}

Here are a number of words and allusions from the poem. Some possible definitions or explanations of their meaning are provided.Students are asked to match A with B

Social science and humanities

Generalization of scientific results 
Group A

grandpa walt

passage to India

lungi

egalitarianism

biblical deluge

Beau Brummell

poncho

Honchos

Superstrings

Wading

Kilted
Group B

poem

an Amirican poet

friend of the Prince Regent

a fictional character in the Marvel Universe

pre-historic great flood

Woolen fabric

sarong

Equality of person

to tuck up (as a skirt)

shallow pool for children

vibrating and hypothetical string

\section{Task 6}

Helping students with the language of the poem, teacher will facilitate the teacher-students interaction:

a)teacher asks if there is unusual or deviant language in the poem, students could be asked to work on activities exploring more normative uses of language. - Understanding individual words in the poem (e.g. sartorial hegemony, sartorial equality, neo imperialism, subaltern and so on - particularly difficult since the words have theoritical meanig)

- Understanding the metaphorical/symbolic meaning behind phrases or

Lines in the poem (e.g. dipping in pond or river or swimming in a lungi abbreviated into a G-string,). It is observed Haq used familiar and comprehensible terms like 'fig leaf', 'G -string', 'poncho' to explain different styles of wearing 'lungi'. Although, the terms are very helpful in relating with 'lungi', the non-native reader who is not familiar with the attire in real can only conceptualize it

Social science and humanities

Generalization of scientific results 
b) Teacher will ask the students to relate their experience with the subject matter of the poem, "lungi". Then he will further ask if it has any connotation or implied meaning. Teacher will illustrate how throughout the poem the word "lungi" has the symbolic significance as well as the manifestation of resistance and opposition with a view to engaging the learners to aesthetic reading.

Task 7

Teacher will ask the students to write down the answer of the following questions:

1. Who was 'Grandpa Walt'?

2. What does the poet mean by the line 'passage to more than India'?

3. What does the poet mean by 'sartorial equality'?

4. What are the different names of lungi?

5. What is the fundamental topic the poet is talking about?

6. How do the people of Srilanka treat lungi?

7. How do the people of Myanmar treat lungi?

8. What is the poem about?

Task 8

Teacher will help the students to solve the following inferences:

1. Why does the poet want to share his thought with Walt Whitman?

2. Why will not Walt Whitman try lungi once?

3. What does the poet mean by 'them' and us'

4. Why do the western people crinkle their nose towards lungi?

5. Why is the nephew of the poet ashamed of his father?

6. What does the line 'I AM A LUNGT ACTIVIST' refer to?

7. What are the different uses of lungi?

\section{Conclusion:}

Implementing such issues, concerns and ideas involved in using multi-cultural text in language classrooms enhances the scope for bilingual speaker of English to use language. Literary text used in EFL/ESL classrooms should not focus exclusively on the native culture. In addition, there is no need to base the Social science and humanities Generalization of scientific results 
content of literary materials on native-speaker models because multi-cultural text exempts the learner from cultural barrier in language acquisition and makes them conscious of assortments of language. In addition, engaging and retaining students' emotion, post-colonial text accelerates aesthetics reading. The sample task given in this paper for the integration of literature into language classroom can serve as guidelines that teachers may follow based upon their particular classroom needs to enhance the effectiveness of their literary texts for the development of learners' communicative skills in the L2. 
American Journal of Research

№ 8-9 (8-9), August-September 2017 www.journalofresearch.us

info@journalofresearch.us

\section{References}

1. Alam, Fakrul. (2007). Imperial Entanglements and Literature in English.Dhaka: Momin offset press.

2. Crystal, D. 1997. English as a global language. Cambridge: Cambridge University Press

3. Haq, Kaisar.(2012).Published in the Streets of Dhaka: Collected poems.Dhaka:The University Press Ltd.

4. Lazar, G. (1993). Literature and language teaching. London: Cambridge University Press.

5. Maley, A. (1989). Down from the pedestal: Literature as resource. In C. J. Brumfit \& R. A. Carter (Eds.), Literature and the learner: Methodological Approaches (pp. 10-23). London: McMillan.

6. Mitchell, R. and Myles, F. 1998. Theories of second language learning.

Murray, D. E., \& McPherson, P. (2006). Scaffolding instruction for reading the Web. Language Teaching Research, 10, 131-156.

7. Pennycook, A. 1994. The cultural politics of English as an international language.London: Longman.

8. Sevier, M.L. 1994. Using Asian literature in the English language classroom: an avenue into cross-cultural education, Guidelines, 16 (2), 1-15.

9. Tomlinson, B. 2000. Materials for cultural awareness: combining language, literature, and culture in the mind. The Language Teacher, 24 (2), 1525.

10. Vardell, S. M., Hadaway, N. L., \& Young, T. A. (2006). Matching books and readers: Selecting literature for English learners. The Reading Teacher, 59, 734-741.

11. Vethamani, M.E. 2003. New Englishes, new literatures in English: challenges for ELT practitioners. In G. Subramaniam (Ed.), Teaching of Literature inESL/EFL Contexts, (pp. 1-12). Petaling Jaya: Sasbadi. 